\title{
Comparison of the Effects of Thermal Pretreatment, Steam Explosion and Ultrasonic Disintegration on Digestibility of Corn Stover
}

\author{
Dániel Capári ${ }^{1}$, Gyula Dörgö ${ }^{2}$, András Dallos ${ }^{* 3}$ \\ ${ }^{1}$ Department of Chemistry, University of Pannonia, H-8201 Veszprém, P.O. Box 158, Hungary \\ e-mail: capari.daniel@gmail.com \\ ${ }^{2}$ Department of Chemistry, University of Pannonia, H-8201 Veszprém, P.O. Box 158, Hungary \\ e-mail: gyula.dorgo@gmail.com \\ ${ }^{3}$ Department of Chemistry, University of Pannonia, H-8201 Veszprém, P.O. Box 158, Hungary \\ e-mail: dallos@almos.vein.hu
}

\begin{abstract}
The energy demand of the corn-based bioethanol production could be reduced using the agricultural byproducts as bioenergy feedstock for biogas digesters. The release of lignocellulosic material and therefore the acceleration of degradation processes can be achieved using thermal and mechanical pretreatments, which assist to hydrolyze the cell walls and speed the solubilization of biopolymers in biogas feedstock. This study is focused on liquid hot water, steam explosion and ultrasonic pretreatments of corn stover. The scientific contribution of this paper is a comprehensive comparison of the performance of the pretreatments by fast analytical, biochemical, anaerobic digestibility and biomethane potential tests, extended by energy consumptions and energy balance calculations. The effectiveness of pretreatments was evaluated by means of soluble chemical oxygen demand, biochemical oxygen demand and by the biogas and methane productivities. The results have shown that the thermal pretreatment, steam explosion and ultrasonic irradiation of biogas feedstock disintegrated the lignocellulosic structure, increased and accelerated the methane production and increased the cumulative biogas and methane productivity of corn stover in reference to the control during mesophilic anaerobic digestion. The energy balance demonstrated that there is an economical basis of the application of the liquid hot-compressed water pretreatments in a biogas plant. However, the steam explosion and ultrasonication are energetically not profitable for corn stover pretreatment.
\end{abstract}

\section{KEYWORDS}

Liquid hot-compressed water treatment, Steam explosion, Ultrasonic disintegration, Biogas digestion, Corn stover.

\section{INTRODUCTION}

The main feedstock for bioethanol in Europe is the corn grain. The economics of corn-based bioethanol production is aimed to be improved by using more heat-tolerant corn varieties [1] with high starch content and by reduction of the energy demand of the process using renewable energy sources. The biogas obtained from Anaerobic Digestion (AD) of agricultural and distillation byproducts, is useful for production of heat and electricity in combined bioethanol and biogas plants. Furthermore, the digestion of agricultural byproducts leads to an additional quantity of organic manure, because the digestate can be used as an organic fertilizer [2]. The corn stover is the most abundant

\footnotetext{
* Corresponding author
} 
crop residue readily available nowadays in Hungary, with production of 10-11 million tons annually [3], but currently the corn silage is one of the most valuable bioenergy feedstock for biogas digesters [4]. Li et al. [5] have shown that the efficiency and stability of digestion of chicken manure can be improved by addition of corn stover. Xiao et al. [6] have proven the influence of particle size and alkaline pretreatment on the anaerobic digestion of corn stover. Zhou et al. [7] introduced stack-pretreatment to gain higher biogas production from corn stover through solid state anaerobic digestion.

However, the complexity and variability of the lignocellulosic structure hinder the biodegradation, particularly the hydrolysis of the complex organic matter to turn into soluble compounds, which is the rate limiting step of the degradation [8]. This structural resistance can be broken by physical, chemical and biological pretreatment methods [9] or by their combinations [10]. The purpose of pretreatment is to change lignin and hemicellulose structures, reduce cellulose crystallinity, and increase the porosity of the materials [11] (Figure 1). The physical pretreatments include mechanical (grinding, milling, ultrasonic and microwave radiations, gas explosions) and thermal treatment methods (hydrothermal treatment, steaming, steam explosion and freezing).There are chemical and biological methods as well [12]. Two of the most common are the dilute acid-based pretreatment [13] and Ammonia Fiber Expansion (AFEX) [14].

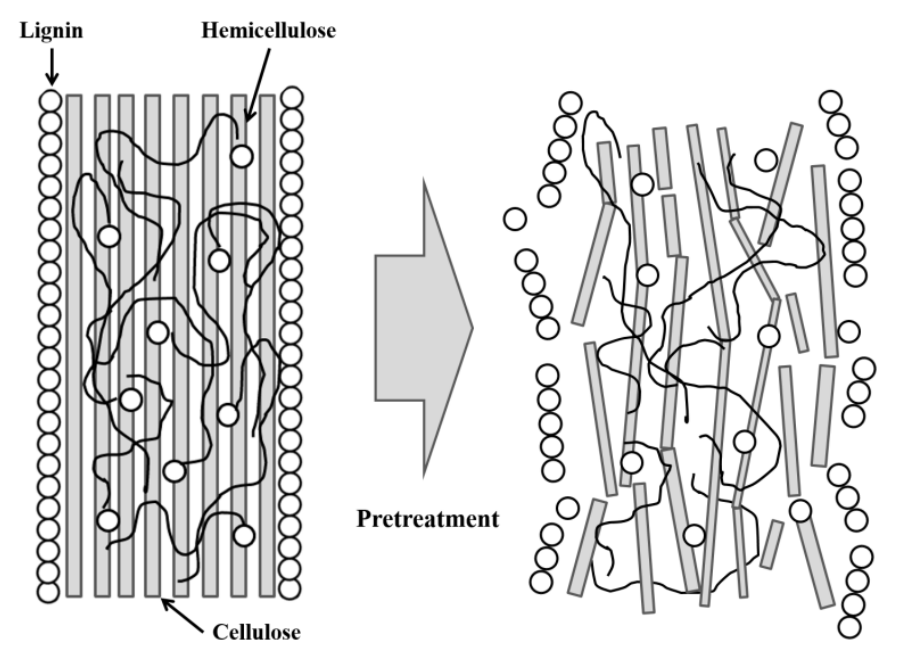

Figure 1. The effect of pretreatment of lignocellulosic material (Kumar et al. [11])

Liquid Hot-Compressed Water (LHCW) is a commonly used hydrothermal pretreatment method. High temperature with high pressure is applied to maintain liquid phase and to avoid vaporization. During the pretreatment, water is penetrated into the cell structure of the biomass, hydrating cellulose, solubilizing hemicellulose, and slightly removing lignin. LHCW pretreatment is highly effective for enlarging the accessible and susceptible surface area of cellulose and improving cellulose degradability for microbes and their enzymes $[15,16]$. After the hydrothermal treatment the biogas production was increased by $7.8 \%$ of pig manure, $67.8 \%$ of municipal sewage sludge and $18.5 \%$ of fruit/vegetable waste [17]. Su et al. [18] observed that the hot water treatment increased the enzymatic digestion of corn leaf and corn stalk. The hot water pretreatment of destarched corn fiber resulted in the dissolution of $58 \%$ of the solids and $75 \%$ of xylan [19]. Weil et al. [20] have shown that hot water pretreatment of corn fiber raised the conversion rate of enzymatic hydrolysis of cellulose.

Steam Explosion (SE) is one of the most effective methods for the pretreatment of lignocellulosic biomass. In this process the biomass is heated with high-pressure steam 
for a certain period of time, then the pressure is reduced to atmospheric pressure as quickly as it is possible. The biomass is undergoes on an explosive decompression by this swift reduction of pressure [21]. The high efficiency of the steam explosion treatment is due to the thermo-mechano-chemical destruction applied in the method. Steam-pretreatment has been used to hydrolyze the hemicellulose and cellulose of softwood for enhanced bioethanol production [22]. Fernández-Bolaños et al. [23] have shown that steam-explosion improved the accessibility of the cellulose and increased the enzymatic hydrolysis yield of seed husks of olive stones. Kaar et al. [24] identified the optimum conditions of the steam explosion cycle to pretreat sugarcane bagasse for conversion into ethanol and pointed out that steam explosion processing optimums are highly feedstock dependent, since different carbohydrates compositions dictate different conditions. The anaerobic fermentation characteristics of green and dried corn straw pretreated by steam explosion method were investigated by $\mathrm{Xu}$ et al. [25], who have shown that the fermentation cycle of green straw is shorter than that of the dried one by 4-7 days. Wang et al. [26] used the steam exploded pretreatment technology to process corn stalk, and demonstrated that the biogas production per unit of pretreated corn stalk increased $16.8 \% \sim 63.2 \%$ than the unexploded corn stalk. Varga et al. [3] proved that steam pretreatment removed the major part of the hemicellulose from the solid material, made the cellulose more susceptible to enzymatic digestion and increased the enzymatic conversion (from cellulose to glucose) of corn stover more than four times, compared to untreated material. The results of Wang et al. [27] indicated that the anaerobic digestion of the stillage remains after high-solids ethanol fermentation from unwashed steam exploded corn stover was able to improve overall content utilization and extract a greater yield of lignocellulosic biomass compared to ethanol fermentation alone.

The biogas yields of anaerobic digestion can be also increased by Ultrasonic Treatments (UT) to support the solubilization of raw materials. During the ultrasonic treatment a cyclic sound pressure is used to disintegrate the cell walls by cavitation. The parameters of the sonication are the power, frequency and time of sonication $[8,28]$. Zhang et al. [29] showed that ultrasonic pretreatments caused indistinctive effects on bio-hydrogen production. Yachmenev et al. [30] demonstrated the acceleration of corn stover enzymatic hydrolysis by low intensity uniform ultrasound, which significantly increased the reaction rate.

The comparison of the various pretreatments and the selection of the suitable processes for the disintegration of corn stover for enhanced biogas production are difficult. This is mostly because of the differences in the microbial communities in different biogas fermenters, in the inocula used, in the substrates cultivated under different conditions and in the methods applied to assess pretreatments: chemical analysis, batch tests or continuous Anaerobic Digestion (AD). Therefore the systematic studies, which deal with the assessment of the several substrate pretreatments on anaerobic digestion using the same inoculum, substrate and microbial community in the same biogas fermenters, are the main novelties of this publication. The coupled determination, interpretation and comparison of the performance of the pretreatments, extended by energy consumption and energy balance calculations are the essential highlights of this paper.

For this reason this work is focused on liquid hot-compressed water, steam explosion and ultrasonic pretreatments of corn stover using both fast analytical, biochemical and biomethane potential AD tests to study and compare the effects of pretreatments on anaerobic digestion without addition of chemicals. The influence of temperature and contact time of thermal treatments and the effect of sonicated energy on breakdown of lignocelluloses on a chemical level have been determined using laboratory scale 
experimental techniques. The effectiveness of thermal and ultrasonic treatments was evaluated by Soluble Chemical Oxygen Demand (SCOD), Biochemical Oxygen Demand of sample during 5 days of incubation $\left(\mathrm{BOD}_{5}\right)$ and by the biogas and methane productivities during mesophilic fermentations.

\section{MATERIALS AND METHODS}

\section{Materials}

Corn stover consists of the leaves and stalks of a new Hungarian corn hybrid "MvMiranda" (FAO 460, year of certification 2007) a cross-bred hybrid, was studied in our investigation as feedstock. The FAO maturity numbers have been calculated using the method proposed by Marton et al. [31]. This maize hybrid was developed by the Agricultural Research Institute of the Hungarian Academy of Sciences (Martonvásár, Hungary), under the brand name of Marton Genetics. Corn hybrid "Miranda" is bred under dry and extensive conditions, the advantage of which can mainly be appraised in such Central-Eastern European markets, where maize growers face the challenges of the lack of precipitation and heat stress that is typical of the area anyway but has been made more frequent due to the general warming-up today. The hybrid is grown for it's high yield and low moisture content. The high starch content of the raw material has improved the species to an optimal feedstock of bioethanol fermentation. The stalks are stable and keep stability even at over-ripening, ensuring safe late harvest conditions without loss. Field experiments demonstrated that new Hungarian hybrids have natural tolerance against western corn rootworm [32]. It was reported by Szőke et al. [33] that Martonvásár hybrids $(\mathrm{Mv})$ have satisfactory tolerance of stalk rot. Post-harvest residue corn stover samples were chopped, homogenized and analyzed for dry substance content (\%DS) $95.09 \%$, organic dry substance content $98.55 \%, \mathrm{C} / \mathrm{N}$ ratio 24.6 and ash content $1.45 \%$. Demineralized water obtained after deionization using cation and anion exchange resins, is defined as water in this work.

The specific heat capacity $\left(C_{p}\right)$ of the corn stover sample in the temperature range of 20-150 ${ }^{\circ} \mathrm{C}$ was determined by DSC measurements with a Setaram C80D high-pressure reaction calorimeter. The temperatures and heat flow values during the DSC measurements were recorded by Calisto Acquisition software, while the data evaluation was done by the Calisto Processing software. The $C_{p}$ values for water were taken from the literature [34]. The temperature dependences of $C_{p}$ of corn stover and water were obtained after fitting a second degree polynomial curve to the experimental data according to eq. (1):

$$
C_{P} /\left(\mathrm{J} \times \mathrm{g}^{-1} \times{ }^{\circ} \mathrm{C}^{-1}\right)=a \times T^{2}+b \times T+c
$$

The data fitting was carried out by Microsoft Excel Solver Add-in module, using the $C_{p}$ values and the corresponding temperatures as input parameters. The coefficients of eq. (1) determined from the experimental $C_{p}$ data of the corn stover sample, as well as for water are given in Table 1.

Table 1. The fitted parameters of eq. (1) for specific heat capacities $\left(C_{p}\right)$ of corn stover and water

\begin{tabular}{cccc}
\hline Sample & $a$ & $b$ & $c$ \\
\hline Cornstover & $-7.53 \mathrm{E}-05$ & 0.0231 & 1.1882 \\
Water & $4.00 \mathrm{E}-05$ & $1.00 \mathrm{E}-04$ & 4.1114 \\
\hline
\end{tabular}




\section{Methods}

Liquid hot-compressed water treatment. The LHCW pretreatment was carried out in a 2 L capacity Parr 4843type high-pressure reactor at the temperatures of 100, 150 and $175{ }^{\circ} \mathrm{C}(0.1,0.5$ and $0.9 \mathrm{MPa}$, respectively) and at various treating times from 10 to 120 minutes. $25 \mathrm{~g}$ of corn stover were used in each experiment and were added to $1,000 \mathrm{~g}$ of water. The suspension was introduced into the thermal reactor at room temperature and heated to the set temperature. The pulp slurry was mixed by a built-in stirrer at $300 \mathrm{rpm}$ during the whole treating process to avoid temperature gradients. After treatment, the reactor was cooled down to $30^{\circ} \mathrm{C}$ by the built-in cooling system of the reactor using cold water-flow and the treated slurry was removed from the vessel.

Steam explosion pretreatment. SE treatment was performed in a steam explosion laboratory unit (Figure 2) consisting of a steam generator (2), a digester vessel (6) and a separator cyclone (8). A 2 L capacity PARR 4843reactorwas used for the production of steam with the temperatures of 185,200 and $215^{\circ} \mathrm{C}$ and working pressures of $1.1 \mathrm{MPa}$, 1.6 $\mathrm{MPa}$ and 2.1 MPa, respectively. The SE unit operated by batches and equipped with a digester vessel (6) of $0.2 \mathrm{~L}$ working volume. The digester vessel was filled with $10 \mathrm{~g}$ feedstock per batch and was heated to the desired temperature, directly with saturated steam led to the vessel, by opening the steam inlet valve (5). No catalysts (additional chemicals) were applied in the process. After the steaming time (1-10 minutes), the expansion valve (7) was opened to rapidly reduce the vessel pressure to the atmospheric one. The steamed sample slurry explosively released into the separator cyclone (8).

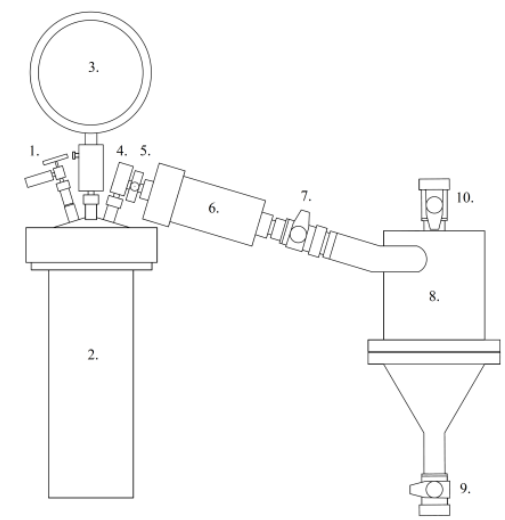

Figure 2. The steam explosion equipment (1. input valve, 2. steam generator (Parr 4843 reactor), 3. pressure gauge, 4. evacuation valve, 5. steam inlet valve, 6. digester vessel, 7. expansion valve, 8. cyclone, 9. sampling valve, 10. steam outlet valve)

Ultrasonic treatment. The ultrasonication was performed in a sonication chamber by usinga Vibracell VCX 750 (Sonics \& Materials, USA) ultrasonic processor, which operated at constant sonication frequency of $20 \mathrm{kHz}$ with maximum power input of 750 $\mathrm{W}$. The radiation was carried out by a $25.4 \mathrm{~mm}$ diameter titan alloy (Ti-6Al-4V) probe with removable tip and maximum amplitude of $35 \mu \mathrm{m}$. Samples of the mixture of corn stover ( $1 \mathrm{~g})$ and water $(99 \mathrm{~g})$ placed in a thermostated vessel, were subjected to ultrasonic pretreatment without additional agitation at different power inputs by adjustment of the amplitude (50, 70 and 100\%) and at various sonication durations of from 1 to 10 minutes for each power level. The temperature of the thermostated vessel was held constant at 25 ${ }^{\circ} \mathrm{C}$ during the treatment by a high-precision thermo-regulator (Huber Kältemaschinenbau $\mathrm{GmbH}$, Germany), to avoid any thermal effects. 
Aliquot parts of the resulting pulp slurries of samples obtained from pre-treatments were used as substrate in the AD test. The rest were filtered to separate the solid fraction from the liquid fraction for analytical measurements ( $\mathrm{SCOD}, \mathrm{BOD}_{5}, \mathrm{pH}$ ). A set of untreated samples, i.e. the blank samples, were also tested for chemical analysis and methane potential by AD as the control points of reference for the treated samples.

Mesophilic anaerobic digestion. The anaerobic degradability of untreated, LHCW, SE and UT pretreated corn stover slurries was determined in laboratory scale, using a fermenter system containing 12 Pyrex batch reactors of $1 \mathrm{~L}$ capacities. Inoculum for the AD tests was taken from the effluent line of an anaerobic pilot fermenter [35] treating a mixture of swine manure and corn stillage (spent mash remaining after bioethanol distillation) at biogas test facility of DENK Ltd (Kövegyürpuszta, Hungary). The batch reactors were inoculated by $700 \mathrm{~g}$ inocula $(\% \mathrm{DS}=8.16 \%)$ and then $100 \mathrm{~g}$ of corn stover pulp slurry samples were added under nitrogen sparging to prevent exposure to air. Furthermore, the digester materials were bubbled with nitrogen gas for 10 minutes to get rid of the air from the liquid phase before each experiment. The batch reactors were kept in a temperature controlled water bath at $37^{\circ} \mathrm{C}$ until they stopped producing biogas. The mesophilic AD tests performed for corn stover substrates including controls were all done in duplicate. During the 36-days of mesophilic AD tests the flow of the produced biogas was measured on-line by digital flow meters and the daily and cumulated biogas volumes were stored digitally. The methane content was determined by gas chromatography.

Analytical and biochemical measurements. The SCOD, $\mathrm{pH}$ and $\mathrm{BOD}_{5}$ measurements were carried out on the liquid fractions after $10 \mathrm{~min}$ centrifugation at 14,000 rpm and 20 ${ }^{\circ} \mathrm{C}$ with a refrigerated universal high-speed centrifuge (UniCen MR, Herolab, Germany) and filtration $(0.45 \mu \mathrm{m})$. Colorimetric SCOD concentration was measured by the Standard Methods procedure [36] using a NanocolorVario Compact heating block (MACHEREY-NAGEL, Germany) and a MultiDirect photometer (Tintometer Lovibond, Germany) according to DIN ISO 15705 [37]. Biochemical Oxygen Demand $\left(\mathrm{BOD}_{5}\right)$ was determined according to EN 1899-1 [38] and EN 1899-2 [39] by using OxiTop Control 6 OC 100 (WTW, Germany) measuring systems. The $\mathrm{pH}$ values were measured by a C831 type $\mathrm{pH}$ meter (Consort, Belgium) with an RA-0903P sensor (Radelkis, Hungary) after two-point $\mathrm{pH}$ calibration $(\mathrm{pH}=4.01 \pm 0.01$ and $\mathrm{pH}=7.00 \pm$ 0.01) using DuraCal pH buffers (Hamilton, Switzerland). The surfaces of the maize leaves and stalks were investigated by a PHILIPS XL30ESEM (enviromental scanning electron microscope), using $20 \mathrm{kV}(\max .30 \mathrm{kV})$ accelerating voltage with a resolution of $3.5 \mathrm{~nm}$. The ESEM were used in Secondary Electron Image mode (SEI) and Backscattered Electron Image mode (BEI).

\section{RESULTS}

\section{Liquid hot-compressed water treatment}

The influence of LHCW pretreatments on SCOD concentration of corn stover slurry at various temperatures and treating times is visualized by $3 \mathrm{D}$ mesh segmentation on Figure 3. The control experiments were performed using non-pretreated corn stover suspension. The results show that LHCW treatment has a positive effect in corn stover disintegration under all the parameters (temperature and treating time) tested, leading to significant increments in SCOD concentration: $+65 \%$ at $100{ }^{\circ} \mathrm{C},+115 \%$ at $150{ }^{\circ} \mathrm{C}$ and + $329 \%$ with an operating time of $30 \mathrm{~min}$, respectively. Both temperature and time have 
positive, but non-linear effects on SCOD, thus at increasing values of these factors the response variable SCOD will also increase. However, the two factors considered (temperature and time) affected the treatment results evaluated in SCOD not in the same extent. The treating time has less effect on the solubilization of corn stover after 30 minutes than the temperature rise. This result is in agreement with that published by Valo et al. [40] who evaluated the effectiveness of thermal treatment of sludge by means of SCOD concentration and obtained that treating time had less influence than temperature in the thermal treatment.

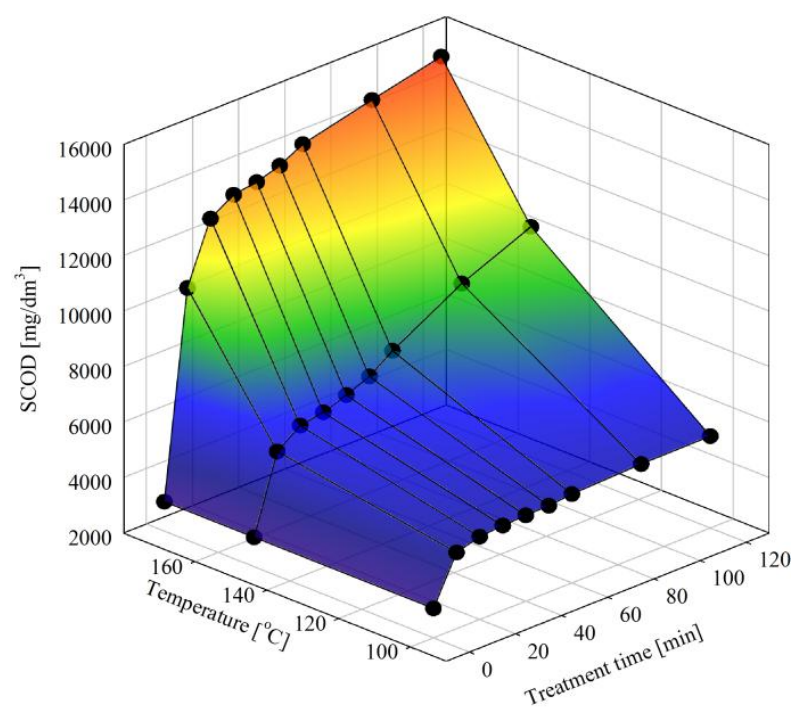

Figure 3. The effect of LHCW pretreatment temperatures and times on SCOD concentration of corn stover suspension $(\bullet$ : experimental data point)

As shown in Figure 3, the higher the treatment temperature, the more organic material is solubilized during the pretreatment. However, higher pretreatment temperature resulted in more acid production during the hydrolysis as reflected by the low $\mathrm{pH}$ level of the corn stover slurry (Figure 4).

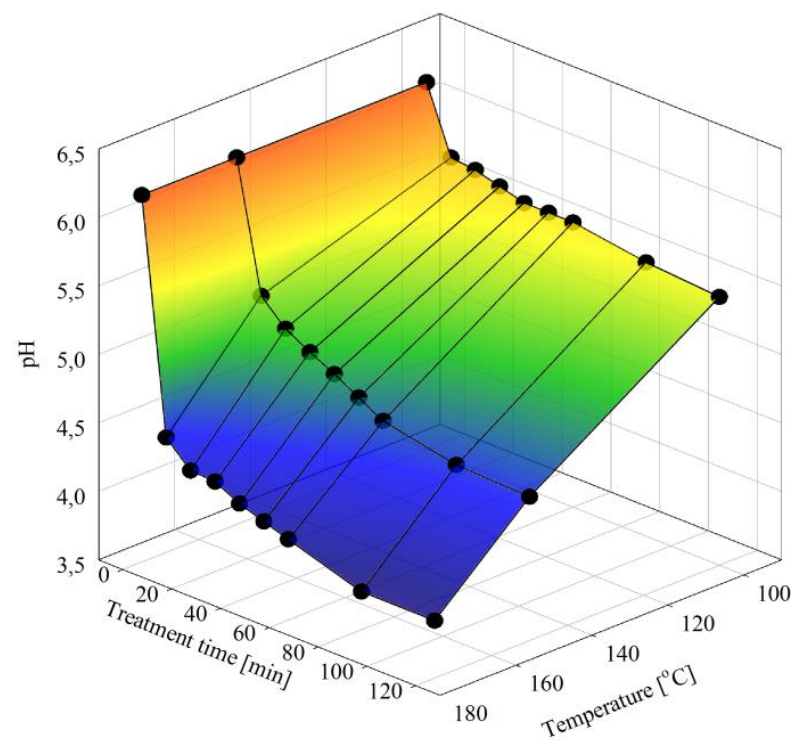

Figure 4. The $\mathrm{pH}$ level of corn stover suspension as the function of LHCW pretreatment time and temperature $(\bullet$ : experimental data point) 


\section{Steam explosion}

The pretreatment temperature and pressure had a significant effect on the digestibility of corn stover. Higher temperatures and pressures resulted in higher solubilization (Figure 5) and lower $\mathrm{pH}$ level of the treated slurry (Figure 6). Compared with untreated corn stover, the SCOD concentration increased by $+434 \%$ at $185{ }^{\circ} \mathrm{C},+503 \%$ at $200{ }^{\circ} \mathrm{C}$ and $+584 \%$ at $215^{\circ} \mathrm{C}$ with an operating time of $3 \mathrm{~min}$, respectively. The pressure effect is quasi-linear and the effect of the duration time can be modeled by an exponential-to-maximum function. The positive pressure effect may be explained by the increased disintegration caused by higher pressure drop. More soluble compounds were released from the straw during the steam explosion and made the corn stover slurry potentially available to subsequent bacterial degradation.

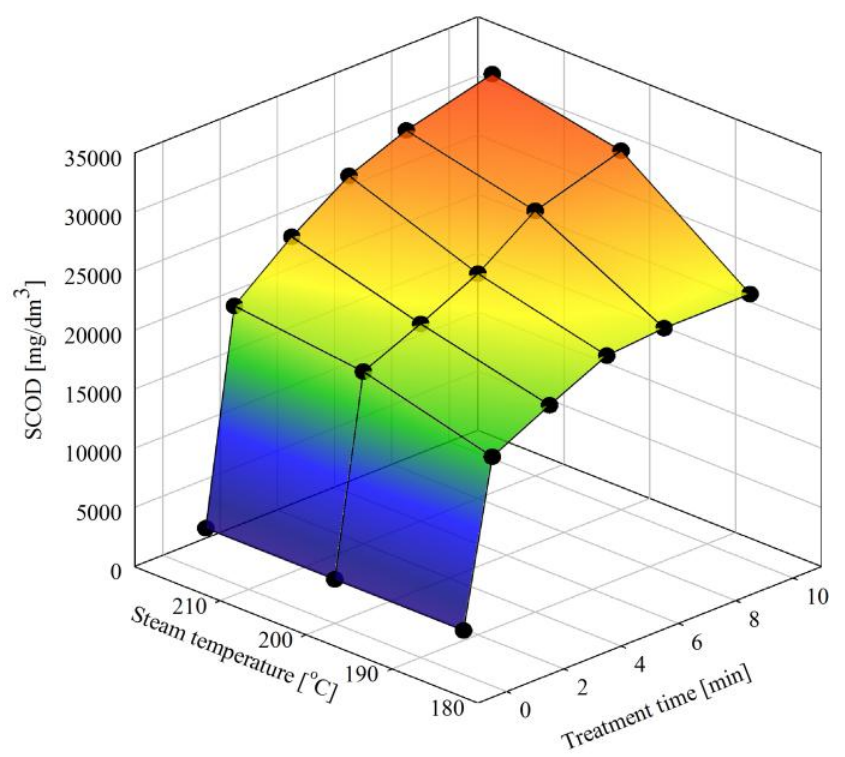

Figure 5. The effect of steam explosion on SCOD concentration levels at various steam pressures as the function of the treatment time ( $\bullet$ : experimental data point)

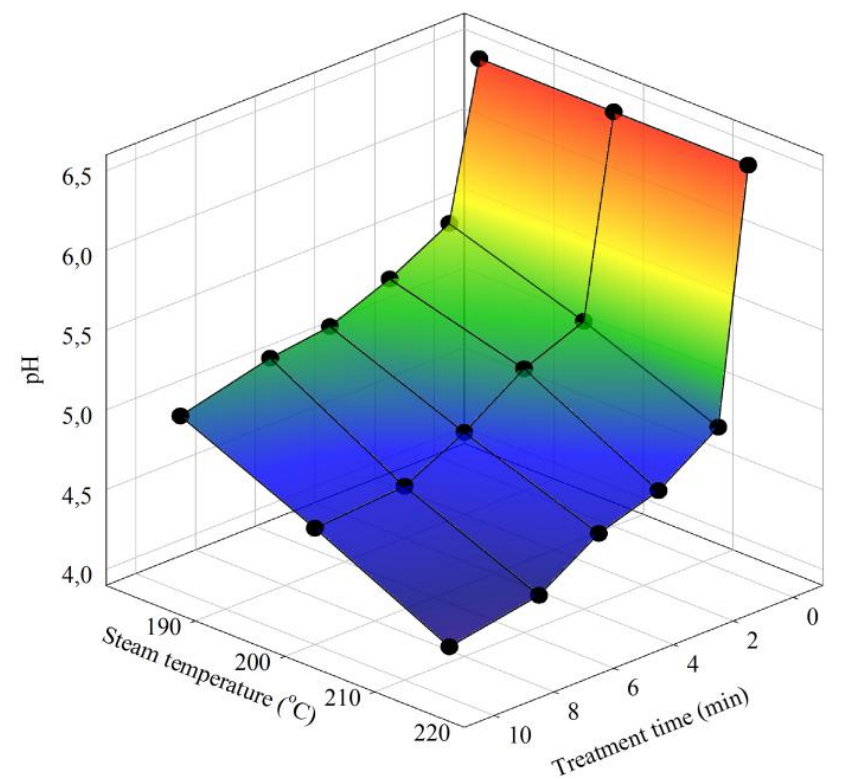

Figure 6. The effect of steam explosion on $\mathrm{pH}$ level at various steam pressures as the function of the treatment time $(\bullet$ : experimental data point) 
Additionally, the $\mathrm{pH}$ value decreased with pretreatment temperature (steam pressure) and pretreatment duration time (Figure 6), which indicates the presence of more acidic degradation product during disintegration of corn stover slurry and demonstrates that steam explosion implying the formation of organic acids. This observation is in agreement of the experiences of Guo et al. [41], who pointed out that steam explosion resulted in a substrate that was most favorable for microbial growth and organic acid production, compounds which would be suitable substrates for conversion to methane by anaerobic digestion.

\section{Ultrasonic pretreatment}

The effectiveness of ultrasonic pretreatment of corn stover was quantified by SCOD concentration of the slurry as a function of pretreatment time and power input in terms of ultrasonic amplitude level $(\%)$ and specific sonicated energy. Results of ultrasonic treatments are shown in Figure 7, where the values of the SCOD concentrations are presented for each value of the ultrasonic amplitude level (\%) and sonication time.

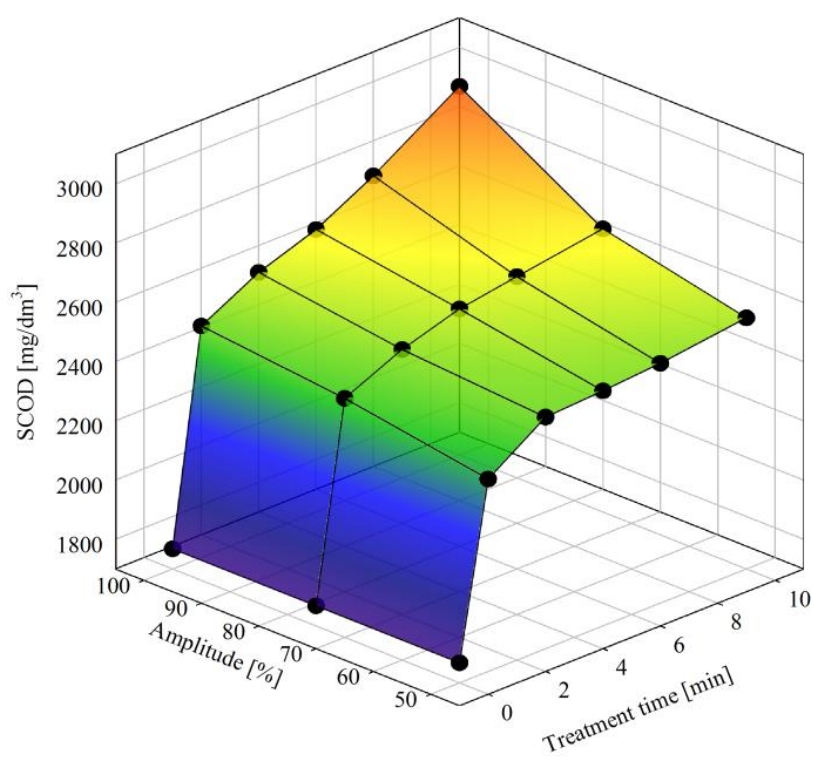

Figure 7. The effect of sonication on SCOD concentration level of corn stover slurry as the function of sonication time and relative ultrasound amplitude ( $\bullet$ : experimental data point)

Three levels of the maximum amplitude: $50 \%, 70 \%$ and $100 \%$ were tested in the study and it can be concluded that slurry SCOD increased with the ultrasonic power, which indicates that the cavitation energy was effective to disrupt the cell walls of the corn leaves and stalks. The SCOD concentration excess can reach $+40 \%$ at $50 \%$ amplitude level, $+44 \%$ at $70 \%$ amplitude level and $+46 \%$ at $100 \%$ amplitude level with an operating time of $3 \mathrm{~min}$, respectively. The ultrasonic power and the pretreatment time affect the SCOD in dissimilar degrees. The rise of SCOD values by treating time is stabilized after 3 minutes. However, the energy effect is quasi-linear and can be well demonstrated by Figure 8, where all the SCOD values are plotted as a function of the specific sonicated energy. The SCOD concentrations were increased by the sonicated energy and no power-saturation phenomenon was observed. The sonicated energies are in the most effective energy region, over the minimal energy of $1,000 \mathrm{~J} / \mathrm{g} \mathrm{DS}$, which is the minimal energy necessary to break cells [42].

The $\mathrm{pH}$ values of the sonicated corn stover slurries decreased slightly with pretreatment time and sonication power (Figure 9), which proves that local temperature 
effects caused by cavitation bubbles were not enough to accelerate the hydrolytic processes resulted in acidic degradation product.

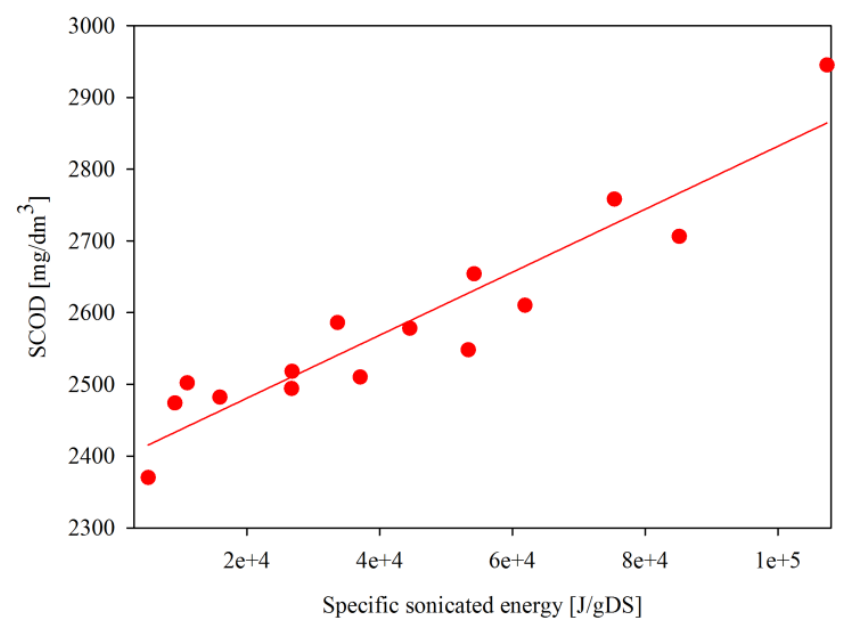

Figure 8. SCOD change in corn stover slurry as a function of specific sonicated energy

(๑: experimental data point, — correlation line with $\mathrm{R}=0.937$ )

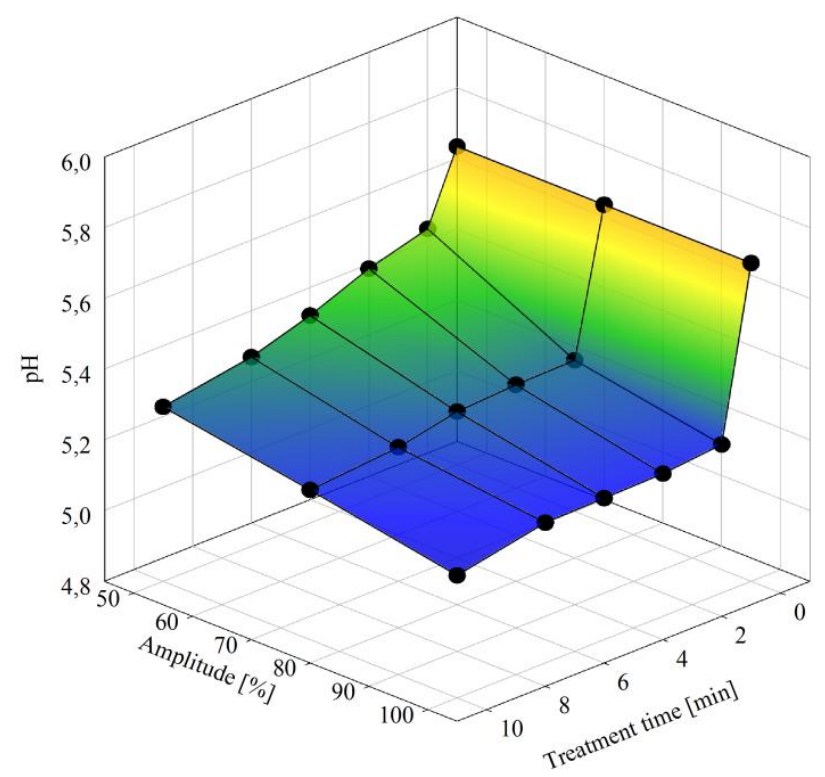

Figure 9. The effect of sonication power on the $\mathrm{pH}$ level of corn stover slurry as the function of the treatment time ( $\bullet$ : experimental data point)

\section{Environmental scanning electron microscopy}

The surfaces of the corn leaves and stalks were investigated by Environmental Scanning Electron Microscopy (ESEM), focusing on the destroyed plant tissues. The ESEM pictures of the surfaces on untreated and steam-explosion-treated maize leaves are given in Figure 10 at $100 \times$ magnification. The surface of the pretreated maize leaves is not uniform (Figure 10b), there is unevenness and cracks on the surface, which is much rougher as the surface of the untreated leaves (Figure 10a). The ESEM pictures of the surfaces on an untreated and ultrasonic-treated maize stalk are given in Figure 11 at 100× magnification. The surface of the maize stalk treated by ultrasound is not homogenous (Figure 11b), there are defective plant issues on the surface, which is much destroyed as the surface of the untreated stalk (Figure 11a). 


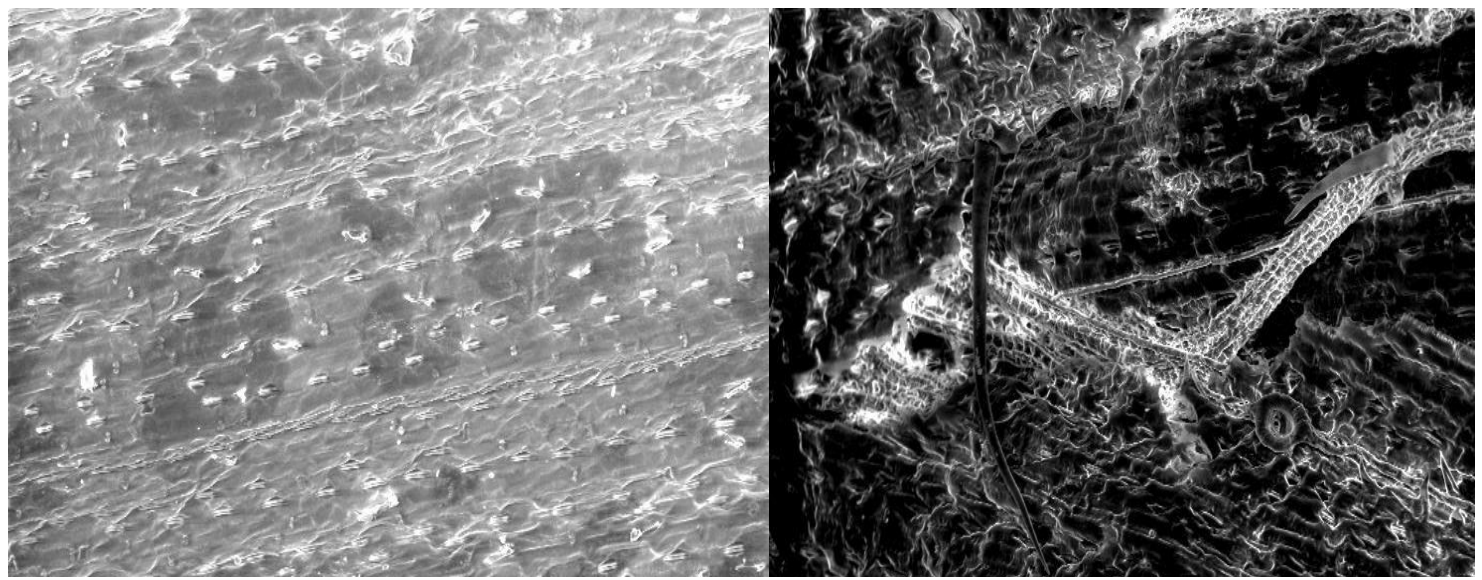

a)

b)

Figure 10. ESEM pictures of the surface on untreated (a); and steam explosion treated (b) maize leaves at $100 \times$ magnification

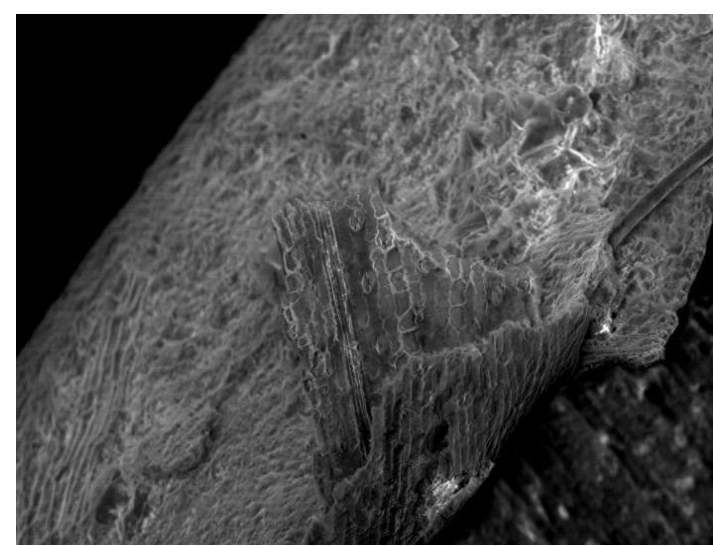

a)

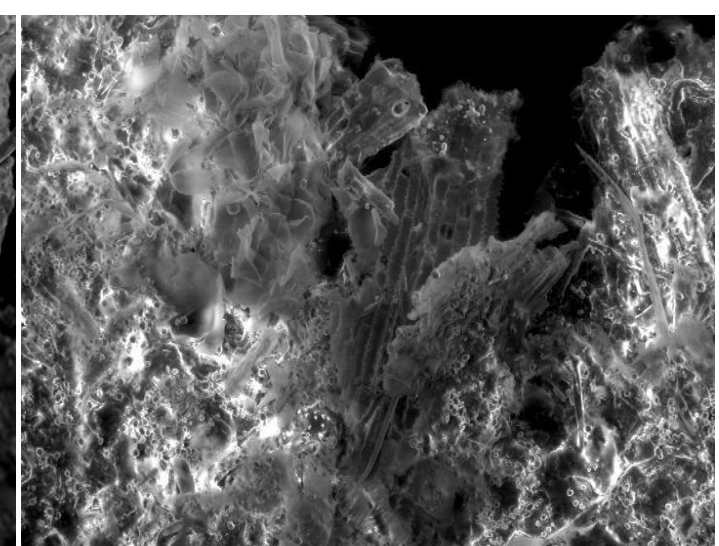

b)

Figure 11. ESEM pictures of the surface on untreated (a); and by ultrasonic treated (b) maize stalks at $100 \times$ magnification

The comparison of the results of the chemical analysis, the SCOD concentration and $\mathrm{pH}$ changes of corn stover slurries in liquid hot-compressed water, steam explosion and ultrasonic pretreatment processes resulted in the conclusion that the most effective disintegration method is the steam explosion for the disruption of corn stover lignocellulosic structure and partial hydrolysis of it molecular components. However, results of these fast methods can only indicate how much the structures of lignocellulosic materials have broken down on a chemical level. Nevertheless, greater breakdown of the lignocellulose structures does not necessarily prove enhanced biogas production because inhibitors for methanogenesis reactions can also be produced through hydrolytic processes during pretreatments. Furthermore, one has to take into account the high energy needs of treatment at elevated temperatures. According to the results of fast chemical analyses (SCOD and $\mathrm{pH}$ ) the optimal conditions for the LHCW, steam explosion and ultrasonic treatment of corn stovers were established as $150{ }^{\circ} \mathrm{C} / 30 \mathrm{~min}$, $200{ }^{\circ} \mathrm{C} / 3 \mathrm{~min}$ and $100 \%$ ultrasound amplitude $/ 3 \mathrm{~min}$ (at $25^{\circ} \mathrm{C}$ ), respectively. However, to study the real effect of optimal conditions of the investigated pretreatments additional biochemical tests like BOD and biomethane potential determinations are absolutely necessary. 


\section{Biochemical oxygen demand}

A comparison of the biochemical oxygen demands of filtrates of corn stover slurries after pretreatment at the optimal conditions is given in Figure 12.
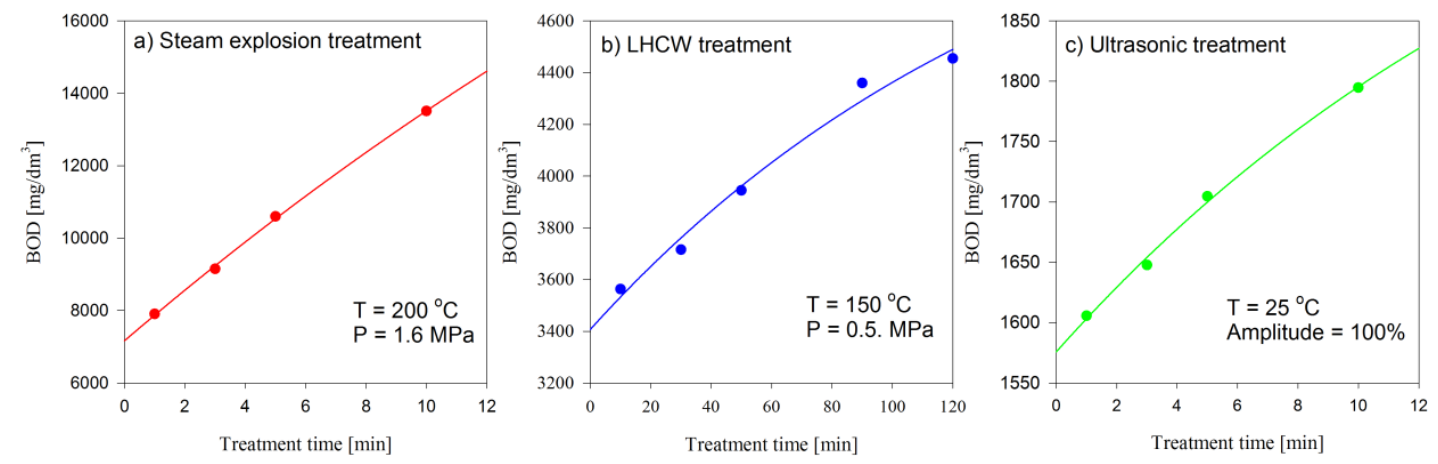

Figure 12. Comparison of the $\mathrm{BOD}_{5}$ test of filtrates of corn stover slurries after various pretreatment methods

The results of the $\mathrm{BOD}_{5}$ tests support the conclusions of the chemical analysis. Actually, all three methods investigated are appropriate for pretreatment of corn stover, because the $\mathrm{BOD}_{5}$ values systematically increased in filtrates of corn stover slurries with the treatment time under the conditions investigated. However, the highest $\mathrm{BOD}_{5}$ values were obtained in filtrates after steam explosion, therefore the steam explosion seems to be the most effective disintegration method to disrupt the lignocellulosic structure of corn stover and to partially hydrolyse its molecular species, resulting in the formation of bacterially digestible substrate.

A comparison of the ratios of $\mathrm{BOD}_{5} / \mathrm{SCOD}$ for various pretreatment methods is given in Figure 13. This ratio, the so called "biodegradability index", is commonly used as a measure for biodegradability.
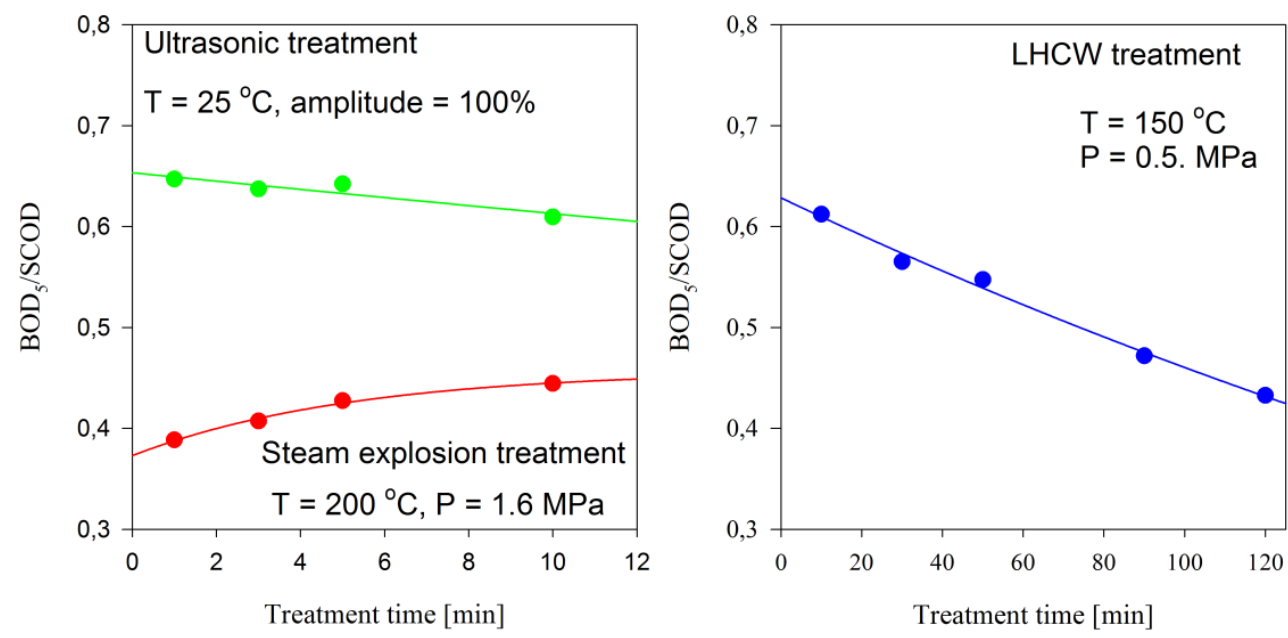

Figure 13. Comparison of the $\mathrm{BOD}_{5} / \mathrm{SCOD}$ ratios of filtrates of corn stover slurries after various pretreatment methods

The $\mathrm{BOD}_{5}$-to-SCOD ratio is in the range of 0.6-0.7 for the ultrasonic treatment (100\% ultrasound amplitude at $25^{\circ} \mathrm{C}$ ), which indicates that filtrates of corn stover pulp slurry after ultrasonication is easily biodegradable, because at low temperature the pretreatment does not produce inhibitors for enzymatic hydrolysis even after long pretreatment time. 
However, in harsh conditions of steam explosion treatments (working pressures of 1.6 MPa at $200{ }^{\circ} \mathrm{C}$ ), lower enzymatic digestibility of corn stover slurry was observed. The obtained $\mathrm{BOD}_{5} / \mathrm{SCOD}$ ratios are between $0.39-0.44$ exhibiting average biodegradability for the steam exploded slurry. Our observations are in agreement with those of Söderström et al., who pointed out that during steam pretreatment, the pentoses and hexoses formed from the hydrolysed hemicellulose and cellulose may be further degraded to furfural, 5-hydroxymethylfurfural HMF, levulinic acid and formic acid, together with other substances, which may cause inhibition in the fermentation step [22]. The presence of the acidic compounds has also been proven by the acidity of the steam exploded corn stover pulp with $\mathrm{pH}$ value of 4.6, as it is given in Figure 6.

The Liquid Hot-Compressed Water (LHCW) pretreatment method $\left(150{ }^{\circ} \mathrm{C}\right.$ at $0.5 \mathrm{MPa}$ ) also causes easily biodegradable feedstock for $\mathrm{AD}$ with $\mathrm{BOD}_{5} / \mathrm{SCOD}$ ratios between 0.61-0.55 at low and moderate treatment times (10-50 minutes), making the corn stover slurry more suitable for biological treatment, and thus increases the potential of cellulose hydrolysis and biogas production. Nevertheless, the higher treatment times of LHCW treatment intensify the cellulose, hemicellulose and lignin degradation, resulting in average enzymatic digestibility of biogas feedstock with BOD5/SCOD ratios of $0.47-0.43$.

\section{Biogas production by mesophilic anaerobic digestions}

Biogas production tests were also undertaken for corn stover slurries pretreated by LHCW, steam explosion and ultrasounds under stated optimal conditions (LHCW: 150 ${ }^{\circ} \mathrm{C} / 30$ min, steam explosion: $200{ }^{\circ} \mathrm{C} / 3 \mathrm{~min}$, and ultrasonic treatment: $100 \%$ ultrasound amplitude $/ 3$ min at $25^{\circ} \mathrm{C}$ ). Daily and final biogas and methane production (normalized volumes at $0{ }^{\circ} \mathrm{C}$ and $101.15 \mathrm{kPa}$ ) were determined as the net contribution of corn stover feedstock by subtraction of the inoculum data from the gross biogas and methane generation values of the inoculated digesters with corn stover substrates. The specific values were calculated by dividing the cumulated gas amount with the dry substance mass (g DS) of the substrates (Table 2). As reference the untreated material was used in the same amount.

Table 2. The dry substance and moisture content of each digesters

\begin{tabular}{ccccccc}
\hline Feedstock & $\begin{array}{c}\text { Digester } \\
\text { No. }\end{array}$ & $\begin{array}{c}\text { g DS from corn } \\
\text { stover pulp }[\mathrm{g}]\end{array}$ & $\begin{array}{c}\text { Water content } \\
\text { of the slurry }[\mathrm{g}]\end{array}$ & Inoculum $[\mathrm{g}]$ & $\begin{array}{c}\text { Total dry } \\
\text { mass }[\mathrm{g}]\end{array}$ & $\begin{array}{c}\text { Moisture content of } \\
\text { the mixture }[\mathrm{g}]\end{array}$ \\
\hline $\begin{array}{c}\text { Corn stover pulp slurry without } \\
\text { pretreatment }\end{array}$ & 1 & 9.6 & 90.9 & 716.5 & 68.1 & 749.4 \\
\hline $\begin{array}{c}\text { Corn stover pulp slurry } \\
\text { pretreated by LHCW }\end{array}$ & 2 & 9.7 & 90.4 & 718.7 & 68.3 & 751.0 \\
\hline $\begin{array}{c}\text { Corn stover pulp slurry } \\
\text { pretreated by steam explosion }\end{array}$ & 4 & 9.6 & 90.2 & 712.4 & 67.7 & 745.0 \\
\hline Corn stover pulp slurry & 6 & 10.0 & 90.2 & 714.7 & 68.3 & 747.1 \\
\hline pretreated by ultrasonication & 8 & 9.6 & 89.8 & 719.0 & 68.3 & 750.6 \\
\hline \multirow{2}{*}{ Inoculum } & 9 & 9.7 & 90.7 & 716.7 & 68.0 & 749.4 \\
\hline & 10 & - & 90.3 & 720.2 & 68.5 & 752.2 \\
\hline
\end{tabular}

Figure 14 demonstrates a typical comparison of the gross and net specific cumulative biogas yields of steam exploded corn stover substrate with that of the inoculum.

The net averaged daily and final biogas and methane production with standard deviations between the duplicates were presented as the function of the digestion time in 
Figure 15 and 16. The graphical representations of the variabilities of the experimental data are given on the graphs by error bars to indicate the uncertainty in the reported measurements. In agreement with the results of chemical analytical and biochemical tests after pretreatment, the specific total biogas and methane yields obtained for treated corn stover substrates were significant higher than that of the untreated control. Mondal et al. [43] have also observed that if the pretreatment has a positive effect on digestion, it causes the increase in the SCOD value and also enhances the rate of anaerobic digestion by hydrolysing the complex organic matter to soluble components.

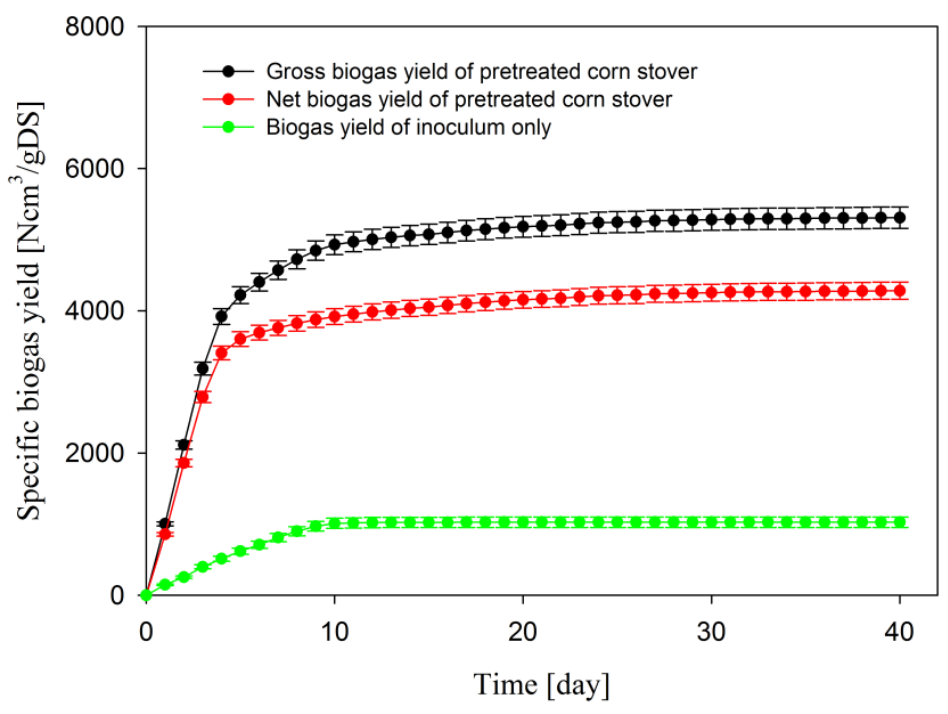

Figure 14. A comparison of the gross and net specific cumulative biogas yields $\left(\mathrm{Ncm}^{3} / \mathrm{g} \mathrm{DS}\right)$ of steam exploded corn stover substrate with that of the inoculum only (averaged data with error bars of the standard deviations)

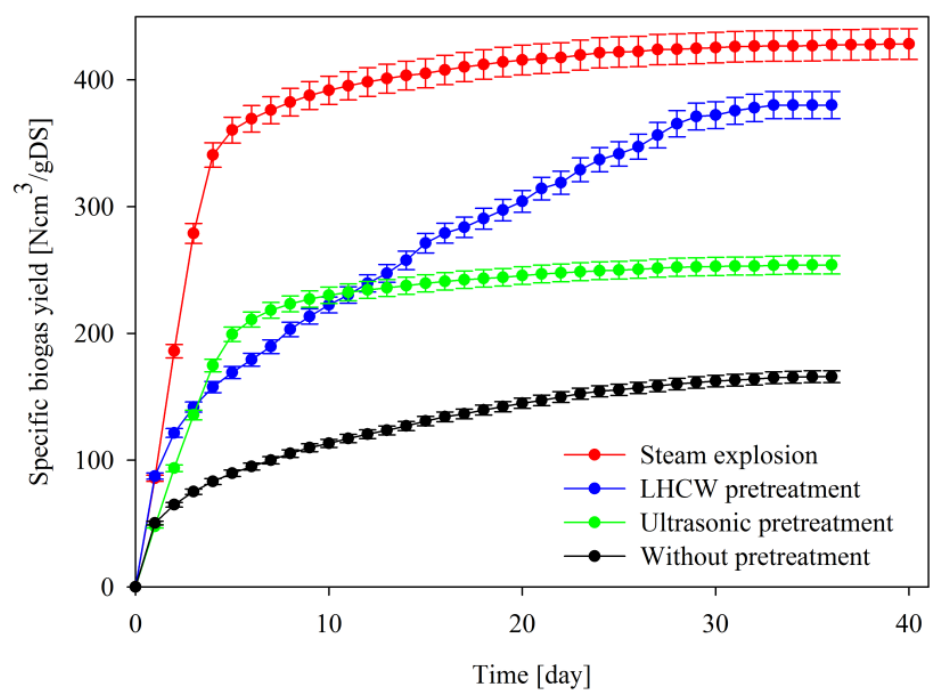

Figure 15. Net specific cumulative biogas yields $\left(\mathrm{Ncm}^{3} / \mathrm{g}\right.$ DS) of corn stover substrates after pretreatments (averaged data with error bars of the standard deviations)

As seen in Figure 15, biogas productions began immediately, without a lag period after starting the degradation of corn stover. The fastest biogas production at the beginning was detected at the steam explosion and hydrothermal (LHCW) pretreatment method. The possible reasons are the more soluble compounds, which were released 
from the corn stover during the steam explosion and LHCW pretreatments and made the corn stover potentially available to subsequent bacterial degradation. High pretreatment temperatures resulted in more acid production during the hydrolysis and higher biogas production rate during the biogas fermentation of corn stover.

The biogas production proceeded in constant and high daily biogas production during hydraulic retention times of 5 days for steam exploded and sonicated substrates and during the whole time period for LHCW treated and untreated substrates. After the steep increase, from the $6^{\text {th }}$ day the rate of the biogas evolution decreased resulting in a plateau of the cumulative curves for steam exploded and sonicated substrates. This observation is important because the application of steam explosion can decrease the cycle time of biogas fermentation and increase the production of biogas with higher methane content. The comparison of the biomethane yields is given by Figure 16. Methane production, the major result of anaerobic digestion of pretreated corn stover, was markedly increased by the three pretreatments. The highest biomethane production rate was observed at the substrates after steam explosion. The biomethane production rate of LHCW treated and ultrasonicated substrate was lower, but double that of the untreated corn stover slurry.

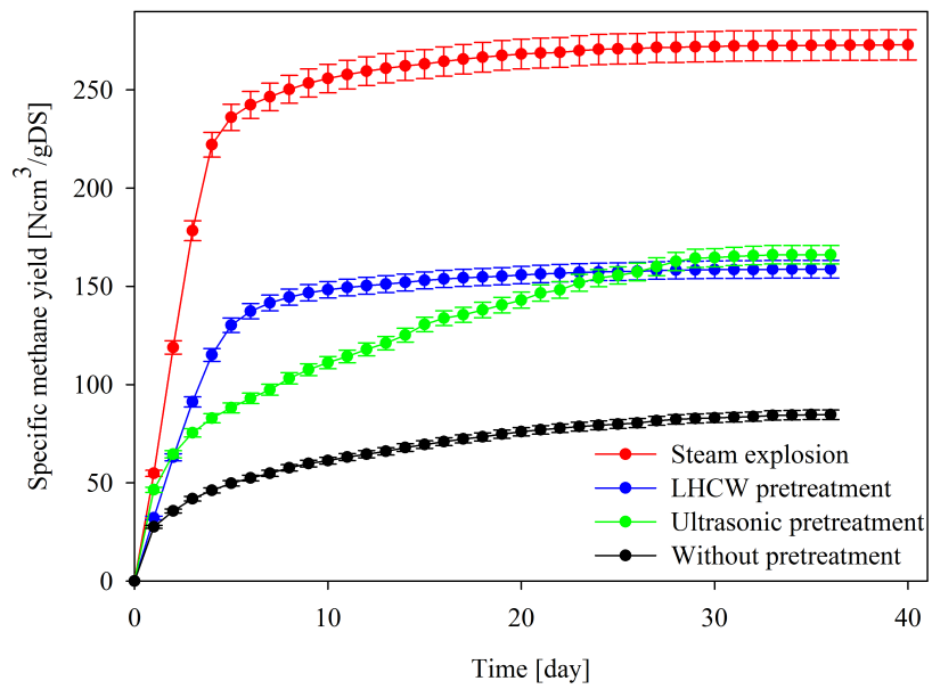

Figure 16. Net specific cumulative methane yields $\left(\mathrm{Ncm}^{3} / \mathrm{g} \mathrm{DS}\right)$ of corn stover substrates after pretreatments (averaged data with error bars of the standard deviations)

\section{Energetic balance}

Although all the three pretreatment methods increase the solubilization of the organic matter, furthermore the structural disintegration and the biogas productivity of corn stover, their application can only be suggested, if the economical basis for doing the pretreatments on-site, in real conditions in a biogas plant, is assured. Therefore, the energy consumption and energy balance of pretreatments were calculated, which is the most important part of the economical basis, besides the investment cost reduction by shorter residence times and production security.

The energetic analysis was based on the concepts that the energy (low calorific value, $\mathrm{LCV}=32.7 \mathrm{MJ} / \mathrm{Nm}^{3}$ ) of the methane content of excess biogas due to the pretreatment covers the energy demands of the pretreatment processes. The heat demand of the LHCW pretreatment was calculated as the heating enthalpy required to the heating up of the corn stover + water mixture to the temperature of the hydrothermolysis. The specific energy demand of steam explosion was determined by estimation of the energy requirement for the steam production. The electrical energy need of ultrasonication pretreatment was calculated 
from of specific sonicated energy (Figure 8) measured and monitored by our sonication device (see subsection "Methods"). The calculated energy demands of the LHCW, steam explosion and ultrasonic pretreatments can be compared with the total caloric value (the amount of energy produced by the complete combustion) increment of the excess biomethane yield of the pretreated corn stover feedstock in Table 3.

The calculated energy balances demonstrated that the energy demand of liquid hot-compressed water is lower than the total caloric value rise of the methane content of excess biogas of the pretreated slurry, which supports the application of the LHCW pretreatments in a biogas plant. Assuming that the produced excess biogas is burned in a gas engine [44], which is a combined heat and electrical power unit with $32 \%$ electrical and $48 \%$ thermal efficiency, the generated heat can cover the heat need of the thermohydrolysis. The excess electrical energy produced is a clear profit, which is fed into the public grid or is utilized within the plant. However, the energy demand of steam explosion and ultrasonic pretreatment is higher than the latent energy increment of the pretreated slurry in form of raised biogas productivity, therefore these two pretreatment processes are energetically not profitable for corn stover.

Table 3. The calculated energy demand of the Liquid Hot-Compressed Water (LHCW), steam explosion and ultrasonic pretreatments and the total caloric value increments with energy balances of the pretreated corn stover feedstock

\begin{tabular}{cccc}
\hline & $\begin{array}{c}\text { Feedstock after } \\
\text { LHCW pretreatment } \\
{[\mathrm{kJ} / \mathrm{kg} \text { slurry }]}\end{array}$ & $\begin{array}{c}\text { Feedstock after steam } \\
\text { explosion pretreatment } \\
{[\mathrm{kJ} / \mathrm{kg} \text { slurry }]}\end{array}$ & $\begin{array}{c}\text { Feedstock ultrasonic } \\
\text { pretreatment } \\
{[\mathrm{kJ} / \mathrm{kg} \text { slurry }]}\end{array}$ \\
\hline Energy demand & 98 & 544 & 1,356 \\
$\begin{array}{c}\text { Total caloric } \\
\text { value increment }\end{array}$ & +170 & +279 & +162 \\
Energy balance & +72 & -265 & $-1,194$ \\
\hline
\end{tabular}

Because the energy balance of the steam explosion of corn stover is negative, their application is only suggested, if the shorter cycle time of the anaerobic digestion and the shorter residence time of the corn stover feedstock in the fermenter resulted in the design of smaller biogas digester and therefore smaller investment costs. Due to the steam explosion and liquid hot-compressed water pretreatments, the methane yield of the pretreated corn stover slurry reached the $90 \%$ of the enhanced biomethane potential of the pretreated feedstock after 8 days, which is $20 \%$ of the usual hydraulic retention time of an anaerobic digester. This enormous reduction of the retention time can result in reduction of plant investment cost, because the design of a biogas plant is directly linked to its hydraulic retention time [45], and the cost of the digesters is about $14 \%$ of the total capital costs [46]. Aubart and Bully [47] have shown that the decrease of retention time permits a decrease of investment cost of $30 \%$ with a retention time of 7.5 days, and $37 \%$ with a retention time of 5 days. Furthermore, an additional economic basis for doing the pretreatments by steam explosion on-site, in real conditions in a biogas plant, is the production security, i.e. the high cost induced by operation problems (thick floating layer with fiber material, locking of impellors and pipes in biogas plants, high electricity requirements for mixing) caused by non-disrupted macrofibrils of lignocellulosic structure of corn stover. However, the use of the ultrasonic pretreatment is not recommended for corn stover because of the low biomethane potential increment and unfavorable energy balance. 


\section{CONCLUSION}

The results of chemical, biochemical analyses and biogas/biomethane potential test obtained by mesophilic anaerobic digestion have been shown, that LHCW treatment, steam explosion and ultrasonic irradiation are effective biomass pretreatment for increasing the solubilization of the organic matters of corn stover. An increase in structural disintegration of corn leaves and stalks has been detected by scanning electron microscopy. Laboratory testing of anaerobic digestibility of pretreated corn stover have shown that the corn stover has high biogas potential and can serve as easily biodegradable biogas feedstock with biodegradability indices between 0.4-0.7. The steam exploded substrate possess the highest biogas production potential $\left(428 \mathrm{Ncm}^{3} / \mathrm{g} \mathrm{DS}\right)$ during hydraulic retention times of 36 days with $64 \%$ methane content, the steam explosion pretreatment increased the biogas yield by $+158 \%$ and the biomethane yield by $+221 \%$ to $273 \mathrm{Ncm}^{3} / \mathrm{g}$ DS. The LHCW pretreatment increased the biogas yield by $+129 \%$ to $380 \mathrm{Ncm}^{3} / \mathrm{g}$ DS) and the biomethane yield by $+86 \%$ to $158 \mathrm{Ncm}^{3} / \mathrm{g}$ DS. The ultrasonication treatment leads to an increase in the biogas production potential by $+53 \%$ to $254 \mathrm{Ncm}^{3} / \mathrm{g}$ DS with $65 \%$ methane content, and increased the biomethane yield by $+95 \%$ to $166 \mathrm{Ncm}^{3} / \mathrm{g}$ DS. The biomass pretreatment techniques studied in this work can reduce the cycle time even by $50 \%$ and improve the gas production via the disintegration of the complex and compact plant structures of corn stover. The energy consumptionand the energy balance calculations of the pretreatments demonstrated that there is an economical basis of the application of the liquid hot-compressed water pretreatments in a biogas plant by an excess energy yield of $+72 \mathrm{~kJ} / \mathrm{kg}$ corn stover slurry. However, the steam explosion and ultrasonication are energetically not profitable for corn stover pretreatment having energy deficits of $-265 \mathrm{~kJ} / \mathrm{kg}$ corn stover slurry and $-1,194 \mathrm{~kJ} / \mathrm{kg}$ corn stover slurry, respectively.

\section{REFERENCES}

1. Chen, J., Xu, W., Velten, J., Xin, Z. and Stout, J., Characterization of Maize Inbred Lines for Drought and Heat Tolerance, Journal of Soil and Water Conservation, Vol. 67, No. 5, pp 354-364, 2012, http://dx.doi.org/10.2489/jswc.67.5.354

2. Losak, T., Hlusek, J., Zatloukalova, A., Musilova, L., Vitezova, M., Skarpa, P., Zlamalova, T., Fryc, J., Vitez, T., Marecek, J. and Martensson, A., Digestate from Biogas Plants is an Attractive Alternative to Mineral Fertilisation of Kohlrabi, Journal of Sustainable Development of Energy, Water and Environment Systems, Vol. 2, Issue 4, pp 309-318, 2014, http://dx.doi.org/10.13044/j.sdewes.2014.02.0025

3. Varga, E., Reczey, K. and Zacchi, G., Optimization of Steam Pretreatment of Corn Stover to Enhance Enzymatic Digestibility, Appl. Biochem. Biotechnol., Vol. 113-116, pp 509-23, 2004, http://dx.doi.org/10.1385/ABAB:114:1-3:509

4. Kettl, K.-H., Niemetz, N., Eder, M. and Narodoslawsky, M., Optimal Renewable Energy Systems for Regions, Journal of Sustainable Development of Energy, Water and Environment Systems, Vol. 2, Issue 1, pp 88-99, 2014, http://dx.doi.org/10.13044/j.sdewes.2014.02.0008

5. Li, Y., Zhang, R., Chen, C., Liu, G., He, Y. and Liu, X., Biogas Production from Co-digestion of Corn Stover and Chicken Manure under Anaerobic Wet, Hemi-solid, and Solid State Conditions, Bioresource Technology, Vol. 149, pp 406-412, 2013, http://dx.doi.org/10.1016/j.biortech.2013.09.091

6. Xiao, X., Zhang, R., He, Y., Li, Y., Feng, L., Chen, C. and Liu, G., Influence of Particle Size and Alkaline Pretreatment on the Anaerobic Digestion of Corn Stover, BioResources, Vol. 8, No. 4, pp 5850-5860, 2013, http://dx.doi.org/10.15376/biores.8.4.5850-5860 
7. Zhou, S., Zhang, Y. and Dong, Y., Pretreatment for Biogas Production by Anaerobic Fermentation of Mixed Corn Stover and Cow Dung, Energy, Vol. 46, No. 1, pp 644-648, 2012, http://dx.doi.org/10.1016/j.energy.2012.07.017

8. Cesaro, A., Naddeo, V., Amodio, V. and Belgiorno, V., Enhanced Biogas Production from Anaerobic Codigestion of Solid Waste by Sonolysis, Ultrasonics Sonochemistry, Vol. 19, No. 3, pp 596-600, 2012, http://dx.doi.org/10.1016/j.ultsonch.2011.09.002

9. Niemistö, J., Saavalainen, P., Pongrácz, É. and Keiski, P. L., Assessment of Lignocellulosic and Waste-based Feedstocks, Journal of Sustainable Development of Energy, Water and Environment Systems, Vol. 1, Issue 2, pp 58-77, 2013, http://dx.doi.org/10.13044/j.sdewes.2013.01.0005

10. Li, J., Zhang, R., Siddhu, M. A. H., He, Y., Wang, W., Li, Y., Chen, C. and Liu, G., Enhancing Methane Production of Cornstover Through a Novel Way: Sequent Pretreatment of Potassium Hydroxide and Steam Explosion, Bioresource Technology, Vol. 181, No. 4, pp 345-350, 2015, http://dx.doi.org/10.1016/j.biortech.2015.01.050

11. Kumar, P., Barrett, D. M., Delwiche, M. J. and Stroeve, P., Methods for Pretreatment of Lignocellulosic Biomass for Efficient Hydrolysis and Biofuel Production, Ind. Eng. Chem. Res., Vol. 48, No. 8, pp 3713-3729, 2009, http://dx.doi.org/10.1021/ie801542g

12. Wei, Y., Li, X., Yu, L., Zou, D. and Yuan, H., Mesophilic Anaerobic Co-digestion of Cattle Manure and Cornstover with Biological and Chemical Pretreatment, Bioresource Technology, Vol. 198, pp 431-436, 2015, http://dx.doi.org/10.1016/j.biortech.2015.09.035

13. Parmar, I. and Rupasinghe, H. P. V., Optimization of Dilute Acid-based Pretreatment and Application of Laccase on Apple Pomace, Bioresour. Technol., Vol. 124, pp 433-439, 2012, http://dx.doi.org/10.1016/j.biortech.2012.07.030

14. Balan, V., Bals, B., Chundawat, S. P., Marshall, D. and Dale, B. E., Lignocellulosic Biomass Pretreatment using AFEX, Methods Mol. Biol., Vol. 581, pp 61-77, 2009, http://dx.doi.org/10.1007/978-1-60761-214-8_5

15. Zheng, Y., Zhao, J., Xu, F. and Li, Y. B., Pretreatment of Lignocellulosic Biomass for Enhanced Biogas Production, Progress in Energy and Combustion Science, Vol. 42, pp 35-53, 2014, http://dx.doi.org/10.1016/j.pecs.2014.01.001

16. van Walsum, G. P., Alien, S. G., Spencer, M. J., Laser, M. S., Antal Jr., M. J. and Lynd, L. R., Conversion of Lignocellulosics Pretreated with Liquid Hot Water to Ethanol, Applied Biochemistry and Biotechnology - Part A Enzyme Engineering and Biotechnology, Vol. 57-58, pp 157-170, 1996, http://dx.doi.org/10.1007/BF02941696

17. Qiao, W., Yan, X., Ye, J., Sun, Y., Wang, W. and Zhang, Z., Evaluation of Biogas Production from Different Biomass Wastes with/without Hydrothermal Pretreatment, Renewable Energy, Vol. 36, No. 12, pp 3313-3318, 2011, http://dx.doi.org/10.1016/j.renene.2011.05.002

18. Su, D., Sun, J., Liu, P. and Lü, Y., Effects of Different Pretreatment Modes on the Enzymatic Digestibility of Corn Leaf and Corn Stalk, Chinese Journal of Chemical Engineering, Vol. 14, No. 6, pp 796-801, 2006, http://dx.doi.org/10.1016/S1004-9541(07)60014-7

19. Dien, B. S., Li, X. L., Iten, L. B., Jordan, D. B., Nichols, N. N., O’Bryan, P. J. and Cotta, M. A., Enzymatic Saccharification of Hot-water Pretreated Corn Fiber for Production of Monosaccharides, Enzyme and Microbial Technology, Vol. 39, No. 5, pp 1137-1144, 2006, http://dx.doi.org/10.1016/j.enzmictec.2006.02.022

20. Weil, J., Sarikaya, A., Rau, S., Goetz, J., Ladisch, C., Brewer, M., Hendrickson, R. and Ladisch, M., Pretreatment of Corn Fiber by Pressure Cooking in Water, Applied 
Biochemistry and Biotechnology, Vol. 73, No. 1, pp 1-17, 1998, http://dx.doi.org/10.1007/BF02788829

21. Mood, S. H., Golfeshan, A. H., Tabatabaei, M., Jouzani, G. S., Najafi, G. H., Gholami, M. and Ardjmand, M., Lignocellulosic Biomass to Bioethanol, a Comprehensive Review with a Focus on Pretreatment, Renewable and Sustainable Energy Reviews, Vol. 27, pp 77-93, 2013, http://dx.doi.org/10.1016/j.rser.2013.06.033

22. Söderström, J., Pilcher, L., Galbe, M. and Zacchi, G., Two-step Steam Pretreatment of Softwood by Dilute $\mathrm{H}_{2} \mathrm{SO}_{4}$ Impregnation for Ethanol Production, Biomass and Bioenergy, Vol. 24, No. 6, pp 475-486, 2003, http://dx.doi.org/10.1016/S0961-9534(02)00148-4

23. Fernández-Bolaños, J., Steam-explosion of Olive Stones: Hemicellulose Solubilization and Enhancement of Enzymatic Hydrolysis of Cellulose, Bioresource Technology, Vol. 79, No. 1, pp 53-61, 2001, http://dx.doi.org/10.1016/S0960-8524(01)00015-3

24. Kaar, W. E., Gutierrez, C. V. and Kinoshita, C. M., Steam Explosion of Sugarcane Bagasse as a Pretreatment for Conversion to Ethanol, Biomass and Bioenergy, Vol. 14, No. 3, pp 277-287, 1998, http://dx.doi.org/10.1016/S0961-9534(97)10038-1

25. Xu, G. Z., Fan, S. Y., Zhang, B. L. and Liu, J. B., Anaerobic Fermentation Characteristics of Corn Straw Pretreated by Steam Explosion, Advanced Materials Research, Vol. 512-515, pp 334-337, 2012, http://dx.doi.org/10.4028/www.scientific.net/AMR.512-515.334

26. Wang, X. T., Cai, H. Z. and Liu, L. S., Experimental Study on Anaerobic Fermentation of Steam Explosion Pretreated Corn Stalk, Advanced Materials Research, Vol. 183-185, pp 1975-1978, 2011, http://dx.doi.org/10.4028/www.scientific.net/AMR.183-185.1975

27. Wang, Z., ZheLv, Z., Du, J., Mo, C., Yang, X. and Tian, S., Combined Process for Ethanol Fermentation at High-solids Loading and Biogas Digestion from Unwashed Steam-exploded Corn Stover, Bioresource Technology, Vol. 166, pp 282-287, 2014, http://dx.doi.org/10.1016/j.biortech.2014.05.044

28. Apul, O. G. and Sanin, F. D., Ultrasonic Pretreatment and Subsequent Anaerobic Digestion under Different Operational Conditions, Bioresource Technology, Vol. 101, No. 23, pp 8984-8992, 2010, http://dx.doi.org/10.1016/j.biortech.2010.06.128

29. Zhang, K., Ren, N., Guo, C., Wang, A. and Cao, G., Effects of Various Pretreatment Methods on Mixed Microflora to Enhance Biohydrogen Production from Corn Stover Hydrolysate, Journal of Environmental Sciences, Vol. 23, No. 12, pp 1929-1936, 2011, http://dx.doi.org/10.1016/S1001-0742(10)60679-1

30. Yachmenev, V., Brian, C., Klasson, T. and Lambert, A., Acceleration of the Enzymatic Hydrolysis of Corn Stover and Sugar Cane Bagasse Celluloses by Low Intensity Uniform Ultrasound, Journal of Biobased Materials and Bioenergy, Vol. 3, No. 1, pp 25-31, 2009, http://dx.doi.org/10.1166/jbmb.2009.1002

31. Marton, L. C., Szieberth, D. and Csürös, M., New Method to Determine FAO Number of Maize (Zea mays L.), Genetika, Vol. 36, No. 1, pp 83-92, 2004, http://dx.doi.org/10.2298/GENSR0401083M

32. Marton, L. C., Szőke, C. and Pintér, J., Natural Tolerance of Maize Hybrids in Martonvásár Against Western Corn Rootworm (Diabrotica Virgifera Virgifera LeConte), Journal of Agricultural Science, Vol. 38, pp 103-106, 2009.

33. Szőke, C., Rácz, F., Spitkó, T. and Marton, L. C., Date on the Fusariumstalk rot, Maydica, Vol. 54, pp 211-215, 2009.

34. Green, D. and Perry, R., Perry's Chemical Engineers' Handbook, Eighth Edition, McGraw Hill Professional, New York, 2007.

35. Förhécz, J., Regős, J., Göblös, Sz. and Dallos, A., Planning, Construction and Testing of a Biogas Pilot Plant with Mesophilic Biodigester, 37th International Conference of 
Slovak Society of Chemical Engineering, Tatranské Matliare, Slovakia, Book of Proceedings, ISBN 978-80-227-3290-1, Ed.: Markos, J., pp 325, 2010.

36. APHA, Standard Methods for the Examination of Water and Wastewater, 19th ed. American Public Health Association, Washington, DC, USA, 1995.

37. ISO 15705:2002, Water Quality -- Determination of the Chemical Oxygen Demand Index (ST-COD) -- Small-scale Sealed-tube Method (reviewed in 2013), Technical Committee ISO/TC 147, ISO International Organization for Standardization, https://www.iso.org/obp/ui/\#iso:std:iso:15705:ed-1:v1:en, 2013.

38. EN 1899-1, Water Quality - Determination of Biochemical Oxygen Demand after $\mathrm{n}$ days $\left(\mathrm{BOD}_{\mathrm{n}}\right)$ - Part 1: Dilution and Seeding Method with Allylthiourea Acid Addition (ISO 5815:1989, modified); German version EN 1899-1, 1998.

39. EN 1899-2, Water Quality - Determination of Biochemical Oxygen Demand after n days $\left(\mathrm{BOD}_{\mathrm{n}}\right)$ - Part 2: Method for Undiluted Samples (ISO 5815:1989, modified); German version EN 1899-2, 1998.

40. Valo, A., Carrère, H. and Delgenès, J. P., Thermal, Chemical and Thermo-chemical Pre-treatment of Waste Activated Sludge for Anaerobic Digestion, J. Chem. Technol. Biotechnol., Vol. 79, pp 1197-1203, 2004, http://dx.doi.org/10.1002/jctb.1106

41. Guo, P., Mochidzuki, K., Cheng, W., Zhou, M., Gao, H., Zheng, D., Wang, X. and Cui, Z., Effects of Different Pretreatment Strategies on Corn Stalk Acidogenic Fermentation using a Microbial Consortium, Bioresource Technology, Vol. 102, No. 16, pp 7526-7531, 2011, http://dx.doi.org/10.1016/j.biortech.2011.04.083

42. Bourgrier, C., Carrère, H. and Delgenès, J. P., Solubilisation of Waste-activated Sludge by Ultrasonic Treatment, Chem. Eng. J., Vol. 106, pp 163-169, 2005, http://dx.doi.org/10.1016/j.cej.2004.11.013

43. Mondal, M. K. and Banerjee, A., Parametric Evaluation of Digestability of Organic Fraction of Municipal Solid Waste for Biogas Production, Journal of Sustainable Development of Energy, Water and Environment Systems, Vol. 3, Issue 4, pp 416-424, 2015, http://dx.doi.org/10.13044/j.sdewes.2015.03.0031

44. CATERPILAR Gas Generator Specification, http://www.cat.com/en_GB/products/ new/power-systems/electric-power-generation/gas-generator-sets/18486985.html

45. Gebrezgabher, S. A., Meuwisswn, M. P. M., Prins, B. A. M. and Oude Lansink, A. G. J. M., Economic Analysis of Anaerobic Digestion, A Case of Green Power Biogas Plant in The Netherlands, NJAS - Wageningen, Journal of Life Sciences, Vol. 57, pp 109-115, 2010, http://dx.doi.org/10.1016/j.njas.2009.07.006

46. Karellas, S., Boukis, I. and Kontopoulos, G., Development of an Investment Decision Tool for Biogas Production from Agricultural Waste, Renewable and Sustainable Energy Reviews, Vol. 14, pp 1273-1282, 2010 , http://dx.doi.org/10.1016/j.rser.2009.12.002

47. Aubart, C. and Bully, F., Anaerobic Digestion of Pig Manure Results on Farm Scale and New Process, In: Palz, W., Coombs, H., Hall, D. O., (Editors) Energy from the Biomass, Third EC Conference, Boca Raton, CRC Press, pp 537-539, 2006. 